Article

\title{
High Hydrostatic Pressure-Assisted Enzymatic Hydrolysis Affect Mealworm Allergenic Proteins
}

\author{
Abir Boukil ${ }^{1}$, Véronique Perreault ${ }^{1}$, Julien Chamberland ${ }^{1} \oplus$, Samir Mezdour ${ }^{2}$, Yves Pouliot ${ }^{1}$ \\ and Alain Doyen $1, * \mathbb{D}$ \\ 1 Department of Food Sciences, Institute of Nutrition and Functional Foods (INAF), Université Laval, \\ Quebec City, QC G1V 0A6, Canada; abir.boukil.1@ulaval.ca (A.B.); veronique.perreault.5@ulaval.ca (V.P.); \\ julien.chamberland@fsaa.ulaval.ca (J.C.); Yves.Pouliot@fsaa.ulaval.ca (Y.P.) \\ 2 AgroParisTech, UMR782 Paris-Saclay Food and Bioproduct Engineering (SayFood and Bioproduct \\ Engineering), 1, rue des Olympiades, 91077 Massy, France; samir.mezdour@agroparistech.fr \\ * Correspondence: alain.doyen@fsaa.ulaval.ca; Tel.: +1+418-656-2131 (ext. 4054540)
}

Academic Editors: Przemyslaw Lukasz Kowalczewski and Antonio-José Trujillo Received: 12 May 2020; Accepted: 4 June 2020; Published: 9 June 2020

\begin{abstract}
Edible insects have garnered increased interest as alternative protein sources due to the world's growing population. However, the allergenicity of specific insect proteins is a major concern for both industry and consumers. This preliminary study investigated the capacity of high hydrostatic pressure (HHP) coupled to enzymatic hydrolysis by Alcalase ${ }^{\circledR}$ or pepsin in order to improve the in vitro digestion of mealworm proteins, specifically allergenic proteins. Pressurization was applied as pretreatment before in vitro digestion or, simultaneously, during hydrolysis. The degree of hydrolysis was compared between the different treatments and a mass spectrometry-based proteomic method was used to determine the efficiency of allergenic protein hydrolysis. Only the Alcalase ${ }^{\circledR}$ hydrolysis under pressure improved the degree of hydrolysis of mealworm proteins. Moreover, the in vitro digestion of the main allergenic proteins was increased by pressurization conditions that were specifically coupled to pepsin hydrolysis. Consequently, HHP-assisted enzymatic hydrolysis represents an alternative strategy to conventional hydrolysis for generating a large amount of peptide originating from allergenic mealworm proteins, and for lowering their immunoreactivity, for food, nutraceutical, and pharmaceutical applications.
\end{abstract}

Keywords: high hydrostatic pressure; mealworm proteins; enzymatic hydrolysis; allergenic proteins; proteomics analysis

\section{Introduction}

Edible insects have garnered increased interest for human consumption due to their high nutritional value and low environmental impact when compared to conventional livestock. Moreover, edible insects were targeted as a potential alternative protein resource to address the problem of a global food crisis. In Western countries, mealworm (Tenebrio molitor) is of particular interest, being evidenced in recent years by several publications related to protein quality and the improvement of techno-functional properties [1-3]. However, recent studies described an allergenic risk that was related to the consumption of edible insects due to potential cross-reactivity with other arthropods, especially crustaceans [4-6]. Tropomyosin, arginine-kinase, but also other insect proteins, such as larval cuticle protein, myosin light, and heavy chain, as well as troponin, are potentially involved in allergenic reactions in cross-reactivity with other allergenic species (shrimp, prawn, and crab) $[5,7,8]$. Consequently, particularly for consumers with a food allergy to crustaceans, it is necessary to consider the risk of an allergic reaction after consuming edible insects. 
Different food processing methods, such as boiling [9,10], autoclaving [11], extrusion [12], microwave [13], pulsed-electric field [14], ultrasound [15], and HHP [16,17], may alter the intrinsic structure of food proteins and, consequently, decrease their allergenic properties. These processes may be coupled to enzymatic hydrolysis to further decrease the allergenicity of a wide range of conventional food proteins and generate protein hydrolysates that could potentially be integrated into specific formulations for food-allergic patients [18]. Similar strategies for reducing protein allergenicity were applied to edible insect products. Specifically, Alcalase ${ }^{\circledR}$ and pepsin were used to decrease the protein allergenicity of a wide range of food matrices, including edible insects. Indeed, Hall et al. [19] demonstrated that increasing the degree of hydrolysis (DH) of cricket proteins after proteolysis by Alcalase ${ }^{\circledR}$ positively impacted their bioactive potential while lowering the reactivity to tropomyosin. Van Broekhoven, Bastiaan-Net, de Jong, and Wichers [5] showed that mealworm protein allergenicity decreased significantly after heat processing and in vitro digestion by pepsin. Additionally, the application of microwave-assisted enzymatic hydrolysis by Alcalase ${ }^{\circledR}$ to cricket protein was an efficient method for generating hypoallergenic peptide fractions [20].

High hydrostatic pressure (HHP), a non-thermal technology that applies isostatic pressure from 100 to 1,000 MPa, induces the modification of secondary, tertiary, and quaternary structures of proteins, causing protein unfolding due to the rupture of noncovalent bonds (hydrogen, hydrophobic, and ionic bonds) [21]. The use of HHP combined with diverse enzymes to reduce protein allergenicity has been previously reviewed [18]. However, HHP-assisted enzymatic hydrolysis to modify allergenic protein digestion from edible insects has not yet been reported. Consequently, the aims of this preliminary work were 1) to apply HHP in combination with enzymatic hydrolysis by Alcalase ${ }^{\circledR}$ or pepsin to generate protein hydrolysates from mealworm meal and 2) to evaluate different pressurization strategies (applied as a pretreatment before enzymatic hydrolysis or simultaneously with enzymatic hydrolysis) to potentially improve the in vitro digestion of mealworm allergenic proteins.

\section{Materials and Methods}

\subsection{Raw Material and Preparation of Mealworm Samples}

Mealworm (Tenebrio molitor) meal powder was purchased from Entomo Farms (Norwood, ON, Canada). The meal was suspended in a Tris- $\mathrm{HCl}$ solution ( $\mathrm{pH} 7)$ at a concentration of $5 \% \mathrm{w} / \mathrm{V}$ and stirred for $60 \mathrm{~min}$ at room temperature. Finally, the insect suspension was stored overnight at $4{ }^{\circ} \mathrm{C}$ prior to enzymatic hydrolysis.

\subsection{Proximate Composition of Mealworm Meals}

The crude fat content was obtained after hexane extraction based on a Soxhlet method (AOAC 960.39). The moisture and ash contents were determined by the Association of Official Analytical Chemists (AOAC) methods 925.09 and 923.03, respectively. The crude protein content was obtained by the Dumas method (Rapid Micro N Cube, Elementar, Langenselbold, Germany) while using a protein-to-nitrogen conversion factor of 4.76 [22]. The chitin content was determined according to the method described by Spinelli et al. [23]. Proximate composition of mealworm meal on dry basis was $45.8 \pm 0.2$ protein, $15.5 \pm 0.9$ lipid, $5.2 \pm 0.0$ ash, and $7.7 \pm 1.0$ chitin.

\subsection{High Hydrostatic Pressure-Assisted Enzymatic Hydrolysis of Mealworm Proteins}

Enzymatic hydrolysis of mealworm proteins was performed prior to (pretreated) or during (simultaneous) pressurization while using a laboratory scale HHP system (Mini FoodLab FPG5620, Stansted Fluid Power LTD, Essex, UK) with a rate of pressurization of $50 \mathrm{MPa} / \mathrm{min}$. The pressure system has a maximum capacity of $900 \mathrm{MPa}$ and a glycol/water solution (30:70) was the pressure transfer fluid. Alcalase ${ }^{\circledR}$ (Subtilisin from Bacillus licheniformis, Sigma Aldrich, St. Louis, MO, USA) and pepsin (BD Difco, Franklin Lakes, NJ, USA) were the enzymes used for hydrolysis. The pressure and duration parameters applied during enzymatic hydrolysis for both pretreated and simultaneous 
conditions were $380 \mathrm{MPa}$ for $1 \mathrm{~min}$. The specific value of $380 \mathrm{MPa}$ was chosen because Zhang et al. [24] demonstrated a significant decrease of Alcalase ${ }^{\circledR}$ activity when the pressure reached $400 \mathrm{MPa}$, which indicated that this level of pressurization induced partial denaturation of the enzyme. Similarly, Curl and Jansen [25] observed that the activity of pepsin that was retained when diluted in a buffer solution at pH 1.9 was close to $100 \%$ at $400 \mathrm{MPa}$, but decreased drastically at higher pressures.

For pretreatment experiments, the mealworm meal suspension was first pressure-treated at $380 \mathrm{MPa}$ for $1 \mathrm{~min}$ and then hydrolyzed at atmospheric pressure $(0.1 \mathrm{MPa})$ while using Alcalase ${ }^{\circledR}$ or pepsin. The choice of these enzymes was based to their ability to hydrolyse the chitin-protein complex from arthropods and, consequently, to improve the recovery of separate protein and chitin separately, as described by Le Roux et al. [26] and De Holanda and Netto [27], respectively. Moreover, Alcalase ${ }^{\circledR}$ and pepsin were already used to decrease protein allergenicity in edible insect matrices $[5,19]$. The hydrolysis parameters for Alcalase ${ }^{\circledR}$ were an enzyme/substrate $(\mathrm{E} / \mathrm{S})$ ratio of $0.03 \% \mathrm{w} / \mathrm{w}$ at $\mathrm{pH}$ 8.5 and $60{ }^{\circ} \mathrm{C}$ for $120 \mathrm{~min}$. The pepsin hydrolysis conditions were an E/S ratio of $0.25 \% \mathrm{w} / \mathrm{w}$ at $\mathrm{pH}$ 2.0 and $40{ }^{\circ} \mathrm{C}$ for $240 \mathrm{~min}$. Hydrolysis durations of 120 and $240 \mathrm{~min}$ were determined as optimal for inducing the separation of the chitin-protein complexes in initial edible insect meals (results not shown) and consequently improved the recovery of protein/peptide fraction in the hydrolysates. For the simultaneous treatment condition, Alcalase ${ }^{\circledR}$ or pepsin enzyme, at the same E/S ratio, $\mathrm{pH}$, and temperature as the pretreated condition, were added to the insect meal suspensions $(5 \% \mathrm{w} / \mathrm{V})$ before pressurization. The mixture of mealworm suspension and enzyme was also pressure-treated at $380 \mathrm{MPa}$ for $1 \mathrm{~min}$. An external thermoregulation system was used to maintain the enzyme's optimal temperature (60 and $40{ }^{\circ} \mathrm{C}$ for Alcalase ${ }^{\circledR}$ and pepsin, respectively) during pressurization. At the end of pressure treatment, decompression was instantaneous and mealworm samples were recovered. The remaining duration of hydrolysis (total hydrolysis of 120 and 240 min for Alcalase ${ }^{\circledR}$ and pepsin, respectively) was carried out at $0.1 \mathrm{MPa}$ (atmospheric pressure) with constant $\mathrm{pH}$ and temperature control. The $\mathrm{pH}$ was controlled during control and pretreatment conditions, but not during simultaneous treatment $(1 \mathrm{~min})$, since it was not possible to open the reactor pressure vessel. However, it was controlled after pressure treatment and until the end of the hydrolysis. The control condition consisted of mealworm suspension $(5 \% \mathrm{w} / \mathrm{V})$ that was digested at atmospheric pressure (0.1 MPa) for 120 and 240 min with Alcalase ${ }^{\circledR}$ and pepsin, respectively. During the hydrolysis step, and for all conditions (control, pretreated, and simultaneous digestions), a sample of mealworm hydrolysate was collected every $2 \mathrm{~min}$ for the first $10 \mathrm{~min}$ of hydrolysis and then every $30 \mathrm{~min}$ until the end of digestion. Samples that were collected during and at the end of hydrolysis were immediately immersed in a $90^{\circ} \mathrm{C}$ water bath for $5 \mathrm{~min}$ to inactivate the enzyme and then centrifuged at $9000 \times g$ for $10 \mathrm{~min}$. Supernatants, corresponding to soluble peptide fractions and potential non hydrolyzed soluble proteins, were recovered and stored at $5^{\circ} \mathrm{C}$ until analysis.

\subsection{Analysis}

\subsubsection{Determination of the Degree of Hydrolysis}

The degree of hydrolysis (DH), which is the proportion of peptide bonds released during in vitro protein digestion, was calculated according to the method that was described by Church et al. [28] for mealworm hydrolysates collected during and at the end of enzymatic hydrolysis, for control, pretreated, and simultaneous conditions. Briefly, $150 \mu \mathrm{L}$ of mealworm hydrolysates (5\% w/V) diluted by a factor of 60 was added to $3 \mathrm{~mL}$ of o-phthaldialdehyde (OPA) reagent. The mixture was incubated at room temperature for $2 \mathrm{~min}$, transferred to polystyrene cuvettes and the absorbance at $340 \mathrm{~nm}$ measured in an Agilent 8453 UV-Visible spectrophotometer (Agilent Technologies, Santa Clara, CA, USA). DL-leucine was used as a standard with concentrations ranging from $0.75 \mathrm{mM}$ to $3 \mathrm{mM}$. All of the samples were analyzed in triplicate. The DH was calculated using Equation (1):

$$
\mathrm{DH}(\%)=\left[\frac{h}{h t o t}\right] \times 100
$$


where $h_{\text {tot }}$ of mealworm was determined from the amino acid composition of the protein, as the sum of mmols of the individual amino acids per $\mathrm{g}$. The $h_{\text {tot }}$ used in this study was $8.64 \mathrm{meq} / \mathrm{g}$. The values of $(h)$ were obtained by reference to a standard curve of absorbance at $340 \mathrm{~nm}$ versus $\mathrm{mg} / \mathrm{L}$ amino nitrogen (using L-leucine) [29].

\subsubsection{Digestion Profiles of Mealworm Proteins}

The degradation profiles of the mealworm proteins after both pressurization conditions (pretreated and simultaneous) were obtained by sodium dodecyl sulfate-polyacrylamide gel electrophoresis (SDS-PAGE) under reducing conditions and compared to the control samples (enzymatic hydrolysis without pressurization treatment). Fifteen microliters of sample from initial and final hydrolysates $(t=0,120$ and $240 \mathrm{~min}$ ) of both insect species was first diluted in $50 \mu \mathrm{L}$ of deionized water. A volume of $25 \mu \mathrm{L}$ of sample buffer (5\% 2-mercaptoethanol, 95\% Laemmli buffer) (Bio-Rad, Mississauga, ON, Canada) was added to $25 \mu \mathrm{L}$ of each diluted sample. Subsequently, the solutions (hydrolysate and sample buffer) were immersed in a boiling water bath for $10 \mathrm{~min}$ and cooled on ice before injecting $10 \mu \mathrm{L}$ per well. Electrophoresis was performed using 4-20\% TGX Stain-Free polyacrylamide gel (Bio-Rad, Mississauga, ON, Canada) at $15 \mathrm{~mA}$ for $1 \mathrm{~h}$ at room temperature. The proteins were then stained with Coomassie blue ( $1 \mathrm{~g} / \mathrm{L}$ of Coomassie Brilliant Blue R-250, 10\% acetic acid, 40\% ethanol, and 50\% water) and destained with a solution of $10 \% \mathrm{~V} / \mathrm{V}$ methanol and $10 \% \mathrm{~V} / \mathrm{V}$ acetic acid. The MW of insect proteins and peptides were estimated using MW markers (Precision Plus Protein ${ }^{\mathrm{TM}}$ 161-0373 All Blue Prestained Protein Standards, Bio-Rad, Mississauga, ON, Canada). Images of the gels were captured using the ChemiDoc ${ }^{\mathrm{TM}}$ MP Imaging System (ChemiDoc MP, Bio-Rad, Mississauga, ON, Canada).

\subsubsection{Protein Identification by Mass Spectrometry}

Mass spectrometry (MS) analysis was performed by the Proteomics Platform of the Research Center of the Centre Hospitalier Universitaire (CHU) of Quebec City (QC, Canada). First, final hydrolysates (120 or 240 min of hydrolysis) generated by Alcalase ${ }^{\circledR}$ and pepsin in vitro digestion for each condition (control, pretreatment, and simultaneous conditions) were desalted on an Oasis HLB column (Waters, Mississauga, ON, Canada) and the peptides were quantified at $205 \mathrm{~nm}$ while using a nanodrop (ThermoFisher, Waltham, MA, USA). Peptide samples ( $1 \mu \mathrm{g})$ were analyzed by Liquid Chromatography-Mass Spectrometry (LC-MS/MS) on an Ekspert NanoLC425 (Eksigent, Redwood City, CA, USA) coupled to a 5600+ Triple TOF mass spectrometer (Sciex, Framingham, MA, USA) that was equipped with a nanoelectrospray ion source. The peptides were trapped on a pepmap $5 \mathrm{~mm} \times$ $0.3 \mathrm{~mm}$ (ThermoFisher, Waltham, MA, USA) cartridge at $4 \mu \mathrm{L} / \mathrm{min}$ then separated on a self-packed picofrit column (New Objective, Woburn, MA, USA) with Reprosil $3 \mu \mathrm{L},(120 \mathrm{~A}$ C18, $15 \mathrm{~cm} \times 0.075 \mathrm{~mm}$ internal diameter), (Dr Maisch, Ammerbuch, Germany). The peptides were eluted with a linear gradient from $8-35 \%$ solvent B (acetonitrile, $0.1 \% \mathrm{~V} / \mathrm{V}$ formic acid) in $30 \mathrm{~min}$, at $300 \mathrm{\eta L} / \mathrm{min}$. Mass spectra were acquired using a data dependent acquisition mode and Analyst software version 1.7 (Sciex, Framingham, MA, USA). Each full scan mass spectrum (400 to 1,250 m/z) was followed by collision-induced dissociation of the twenty most intense ions. Dynamic exclusion was set for a period of $20 \mathrm{~s}$ and a tolerance of $100 \mathrm{ppm}$.

Mascot Generic Format (MGF) peak list files were created using Protein Pilot software (version 4.5, Sciex, Concord, ON, Canada). The MGF sample files were then analyzed using Mascot software (version 2.5.1, Matrix Science, London, UK). Uniprot databases were used to detect contaminants and align protein sequences while using the Tenebrionidae family $(24,496$ entries) database, assuming no enzyme. A fragment ion mass tolerance of $0.100 \mathrm{Da}$ and a parent ion tolerance of 0.100 Da were used. The deamidation of asparagine and glutamine, and oxidation of methionine, were specified in Mascot as variable modifications.

Scaffold software (version 4.8.4, Proteome Software Inc., Portland, OR, USA) was used to validate MS/MS-based peptide and protein identifications. Peptide identifications were accepted if they could be established at a probability greater than $95.0 \%$ by the Scaffold Local False Discovery Rate (FDR) 
algorithm. Protein identifications were also accepted if they could be established at a probability that is greater than $95.0 \%$ and if they contained at least two identified peptides. Protein probabilities were assigned by the Protein Prophet algorithm [30]. Proteins that contained similar peptides that could not be differentiated based on MS/MS analysis alone were grouped to satisfy the principles of parsimony.

\subsection{Statistical Analysis}

The pressurization assays, enzymatic hydrolysis, and proximate composition were performed in triplicate. The DH results were expressed as mean \pm standard deviation (SD). These data were subjected to a one-way analysis of variance (ANOVA) using Sigma Plot 14.0 (Systat Software Inc., Chicago, IL, USA). A 95\% confidence level was used for all analyses.

\section{Results}

\subsection{Mealworm Protein Degradation during Enzymatic Hydrolysis}

Figure 1 presents the degradation of mealworm soluble proteins that were recovered at the beginning, during, and at the end of the enzymatic hydrolysis for control and pressurized conditions (pretreated and simultaneous). Regarding protein profiles during Alcalase ${ }^{\circledR}$ hydrolysis (Figure 1A), a band, whose intensity increased as a function of hydrolysis duration, was detected in wells for control, pretreated, and simultaneous conditions. Whatever the condition, three distinctive bands that corresponded to proteins with molecular weights (MW) close to 10, 20, and $50 \mathrm{kDa}$ were observed. The protein degradation profiles for hydrolysates after 10 and $120 \mathrm{~min}$ of Alcalase ${ }^{\circledR}$ hydrolysis for control, pretreated, and simultaneous conditions were similar. More specifically, the same bands, as listed for control at $\mathrm{t}=0 \mathrm{~min}(10,20$, and $50 \mathrm{kDa})$, were detected, but heavy bands close to $10 \mathrm{kDa}$ were observed after 10 and 120 min of hydrolysis, resulting in mostly peptide fragments. A band with MW between 150 and $250 \mathrm{kDa}$ observed after $10 \mathrm{~min}$ of hydrolysis, and whose intensity was increasing at $120 \mathrm{~min}$ of hydrolysis, was detected for control and pretreatment conditions but was absent at $\mathrm{t}=0 \mathrm{~min}$. When compared to Alcalase ${ }^{\circledR}$, non-distinctive bands were observed for the pepsin control at $\mathrm{t}=0 \mathrm{~min}$ except for the band at $20 \mathrm{kDa}$ (Figure 1B). However, while peptides with molecular weights close to $10 \mathrm{kDa} \mathrm{MW}$ were detected for all conditions, the bands were more intense for simultaneous conditions after 10 and $240 \mathrm{~min}$ of hydrolysis as compared to the pretreatment condition. Under the control conditions, peptides with molecular weight close to $10 \mathrm{kDa} \mathrm{MW}$ were more concentrated after $10 \mathrm{~min}$ of hydrolysis as compared to $240 \mathrm{~min}$.
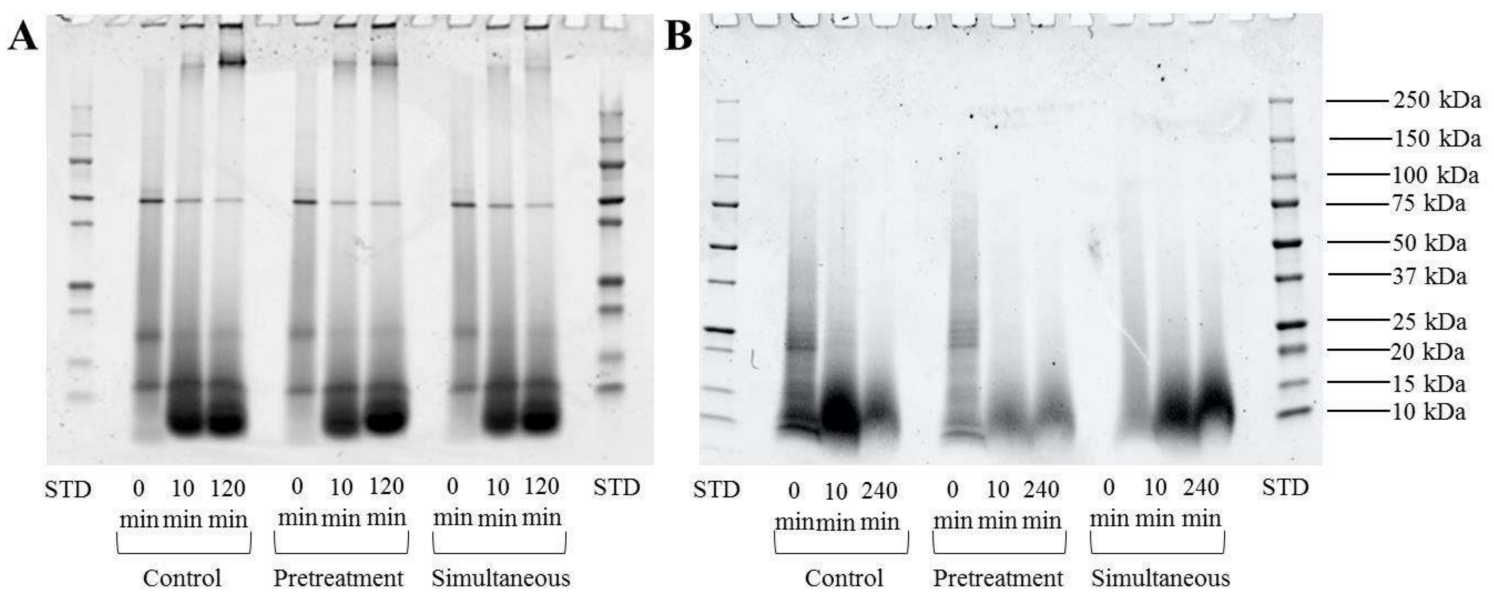

Figure 1. Protein degradation of mealworm proteins during enzymatic hydrolysis by Alcalase ${ }^{\circledR}$ (A) and pepsin $(\mathbf{B})$ for control $(0.1 \mathrm{MPa})$ and pressurization conditions (pretreated and simultaneous at $380 \mathrm{MPa}$ for $1 \mathrm{~min})$. 


\subsection{Effect of High Hydrostatic Pressure Coupled to Enzymatic Digestion on the Degree of Hydrolysis of} Mealworm Proteins

Figure 2 shows the evolution of DH for mealworm proteins digested by Alcalase ${ }^{\circledR}$ and pepsin under three different conditions: without pressure (control), HHP applied as a pretreatment before hydrolysis, and HHP applied simultaneously during in vitro digestion. The degree of hydrolysis during in vitro digestion of mealworm protein by Alcalase ${ }^{\circledR}$ increased rapidly from 0 to 10 min and linearly until the end of hydrolysis $(120 \mathrm{~min})$, no matter the condition (control, pretreatment, and simultaneous conditions) (Figure 2A). The evolution of DH was similar for the control and pretreatment conditions with respective final values of $32.29 \pm 1.90 \%, 37.82 \pm 3.43 \%$, and $29.12 \pm 0.95 \%(p>0.05)$. However, the degree of hydrolysis under HHP (simultaneous condition) was higher than control $(21.75 \pm 1.27 \%)$ and pretreated $(22.20 \pm 1.89 \%)$ conditions up to $60 \mathrm{~min}(p<0.05)(27.15 \pm 2.02 \%)$, but remained similar from 60 to $120 \mathrm{~min}(p>0.05)$.

The evolution of the $\mathrm{DH}$ during mealworm protein hydrolysis by pepsin was similar to that of Alcalase ${ }^{\circledR}$, with values of $35.20 \pm 1.87 \%, 29.01 \pm 3.55 \%$, and $32.31 \pm 1.09 \%$ for the control, pretreated, and simultaneous conditions, respectively $(p>0.05)$ (Figure $2 \mathrm{~B})$. When compared to hydrolysis by Alcalase ${ }^{\circledR}$, the DH increased steadily over time and was lower at the end of hydrolysis (120 min for Alcalase ${ }^{\circledR}$ and $240 \mathrm{~min}$ for pepsin).

\subsection{Determination of Mealworm Allergenic Protein Precursors from Hydrolysates}

Table 1 presents the determination of mealworm allergenic protein precursors from peptides generated after $120 \mathrm{~min}$ of Alcalase ${ }^{\circledR}$ hydrolysis or $240 \mathrm{~min}$ of pepsin hydrolysis in vitro digestion. The total spectrum count (TSC) value, defined as the total number of spectra identified for a protein, is of particular interest, since this parameter is a semi-quantitative measure for a given protein abundance in proteomic studies [31]. Indeed, previous studies have demonstrated that the spectral counts of proteins correlate linearly with protein abundances in complex samples [32-34]. High throughput mass spectrometry identified a total of 110 proteins and close to 2800 spectrum counts. From these proteins, 19 allergenic proteins in mealworm meal were identified from the 161 unique peptides that were generated after Alcalase ${ }^{\circledR}$ or pepsin in vitro digestion of the mealworm proteins. The coverage and TSC ranged from 3 to $70 \%$ and 0 to 106, whatever the conditions (control, pretreatment, and simultaneous) and enzyme (Alcalase ${ }^{\circledR}$ and pepsin). The 19 allergenic proteins were identified according to the publication of Barre et al. in 2018 [35]. The majority of protein MWs ranged from 11 to $51 \mathrm{kDa}(\sim 74 \%)$, but five of the identified proteins ranged from 84 to $123 \mathrm{kDa}$. Most of the identified proteins had good peptide coverage, with $\sim 31 \%$ of proteins having $>10 \%$ of the sequence coverage and $\sim 31 \%$ of proteins having $>20 \%$ sequence coverage. 

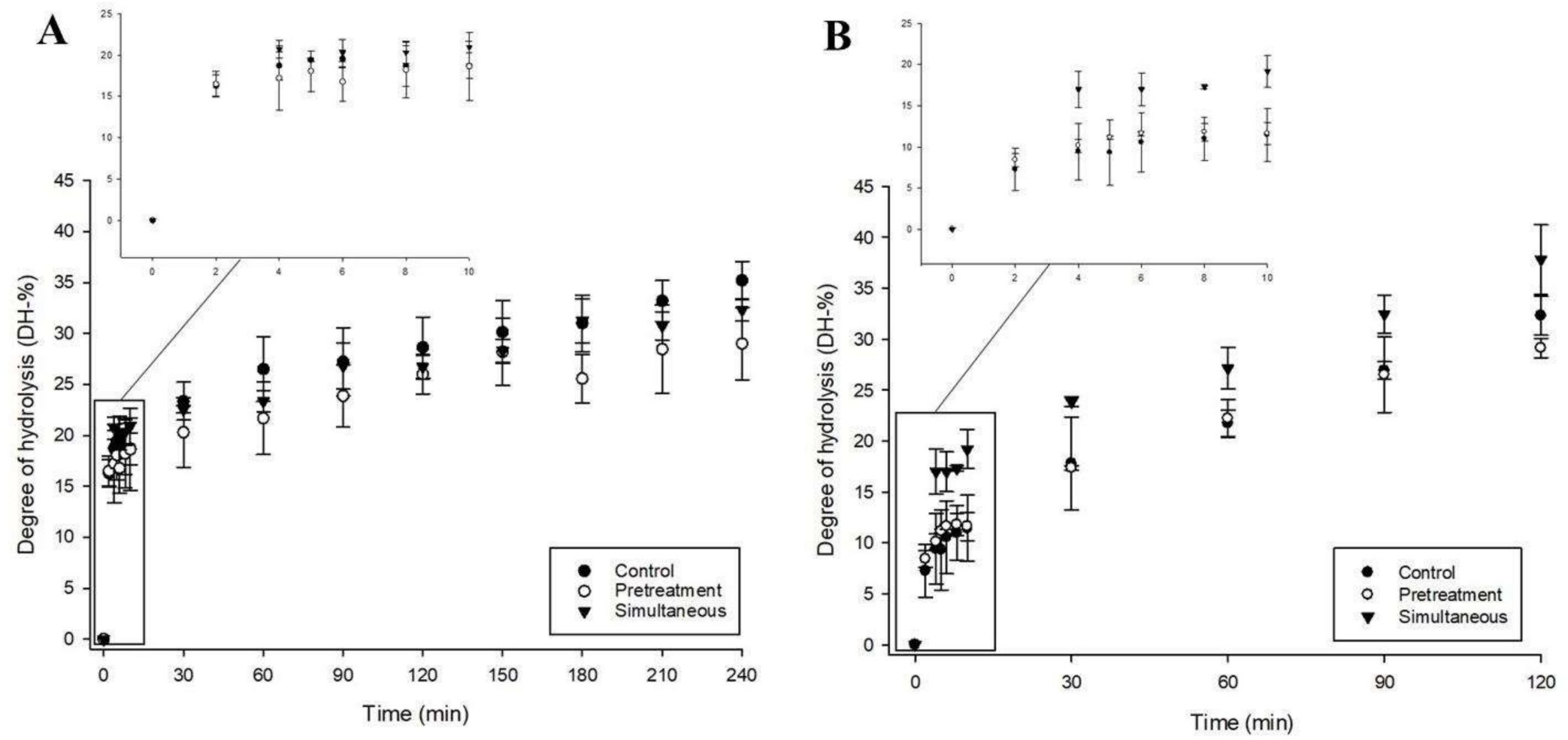

Figure 2. Degree of hydrolysis (\%) of mealworm proteins digested by Alcalase ${ }^{\circledR}(\mathrm{A})$ and pepsin $(\mathbf{B})$ for control $(0.1 \mathrm{MPa})$, pretreated, and simultaneous conditions $(380 \mathrm{MPa})(\mathrm{n}=3 \pm \mathrm{SD})$. 
Table 1. Mealworm allergenic protein precursors from peptides generated after Alcalase ${ }^{\circledR}$ and pepsin in vitro digestion of mealworm proteins.

\begin{tabular}{|c|c|c|c|c|c|c|c|c|c|c|c|}
\hline \multirow[t]{3}{*}{ Protein \# } & \multirow[t]{3}{*}{ Identified Proteins * } & \multirow[t]{3}{*}{ MW (kDa) } & \multirow[t]{3}{*}{ UniProt ID } & \multirow{3}{*}{$\begin{array}{c}\text { Number of Unique } \\
\text { Peptides }\end{array}$} & \multirow{3}{*}{$\begin{array}{c}\text { Coverage } \\
(\%)\end{array}$} & \multicolumn{6}{|c|}{ Total Spectrum Count (TSC) ** } \\
\hline & & & & & & \multicolumn{3}{|c|}{ Alcalase $^{\circledR}$} & \multicolumn{3}{|c|}{ Pepsin } \\
\hline & & & & & & $\mathrm{C}^{1}$ & $\mathbf{P}^{2}$ & $\mathrm{~S}^{3}$ & $\mathrm{C}$ & $\mathbf{P}$ & $\mathrm{s}$ \\
\hline 1 & Myosin heavy chain & 123 & A0A139WDZ4 & 15 & 7 & 2 & 4 & 4 & 21 & 31 & 19 \\
\hline 2 & Myosin heavy chain & 141 & A0A139WE70 & 8 & 6 & 2 & 4 & 6 & 9 & 22 & 10 \\
\hline 3 & Myosin heavy chain & 103 & A0A139WE10 & 2 & 9 & 0 & 0 & 0 & 20 & 0 & 21 \\
\hline 4 & Tropomyosin-1 & 40 & A0A139WAN8 & 3 & 9 & 0 & 0 & 0 & 3 & 2 & 1 \\
\hline 5 & Actin-87E & 42 & D6WF19 & 28 & 39 & 24 & 31 & 51 & 42 & 106 & 71 \\
\hline 6 & Hexamerin 2 & 84 & A0A288EPS5 & 7 & 9 & 4 & 6 & 7 & 11 & 28 & 22 \\
\hline 7 & Hexamerin 1 & 86 & A0A288EIN5 & 7 & 11 & 0 & 0 & 8 & 7 & 13 & 11 \\
\hline 8 & Arginine kinase 1 & 40 & A0A139WNX9 & 7 & 17 & 10 & 14 & 12 & 9 & 28 & 18 \\
\hline 9 & Troponin $\mathrm{T}$ & 46 & D6W953 & 3 & 3 & 0 & 1 & 0 & 3 & 6 & 7 \\
\hline 10 & Troponin C & 17 & D6WZP8 & 1 & 7 & 1 & 1 & 0 & 1 & 2 & 1 \\
\hline 11 & Tubulin beta chain & 50 & D6WSV2 & 10 & 16 & 1 & 1 & 1 & 10 & 15 & 17 \\
\hline 12 & Tubulin alpha chain & 50 & D6WBN7 & 5 & 13 & 1 & 0 & 1 & 5 & 10 & 10 \\
\hline 13 & Alpha-amylase & 51 & P56634 & 6 & 13 & 2 & 1 & 7 & 6 & 21 & 15 \\
\hline 14 & Larval cuticle protein $\mathrm{A} 2 \mathrm{~B}$ & 12 & P80682 & 21 & 70 & 13 & 10 & 16 & 23 & 58 & 52 \\
\hline 15 & Larval cuticle protein F1 & 15 & Q9TXD9 & 13 & 48 & 13 & 9 & 27 & 18 & 42 & 26 \\
\hline 16 & Larval cuticle protein A1A & 18 & P80681 & 5 & 33 & 6 & 6 & 18 & 14 & 58 & 54 \\
\hline 17 & Larval cuticle protein $\mathrm{A} 3 \mathrm{~A}$ & 14 & P80683 & 8 & 58 & 16 & 9 & 21 & 17 & 55 & 59 \\
\hline 18 & Larval cuticle protein 8 & 11 & D6WMB1 & 2 & 15 & 1 & 0 & 4 & 4 & 6 & 2 \\
\hline 19 & Larval / pupal cuticle protein $\mathrm{H} 1 \mathrm{C}$ & 21 & P80686 & 10 & 33 & 0 & 0 & 2 & 14 & 29 & 19 \\
\hline
\end{tabular}

* The probability of protein identification was over $95 \%$. ${ }^{* *}$ The peptide identification probability was ranging from 96 to $100 \% .{ }^{1}$ Control, ${ }^{2}$ Pretreated, and ${ }^{3}$ Simultaneous conditions . 
Globally, the in vitro digestion of mealworm allergenic proteins by pepsin was more efficient than Alcalase ${ }^{\circledR}$, since higher TSC values were obtained for all 19 allergenic proteins (Table 1). Regardless of the condition tested (control, pretreated, and simultaneous), allergenic proteins \#5, 8, 14, 15, 16, and 17 were more susceptible to in vitro digestion by Alcalase ${ }^{\circledR}$, as illustrated by high TSC values $($ TSC $>10)$. Specifically, allergenic proteins \#1, 2, and 6 were more resistant to hydrolysis by Alcalase ${ }^{\circledR}($ TSC $<10)$, whereas proteins \#3, 4, 7, 9, 10,11, 12, 18, and 19 were not digested by this enzyme (TSC values closed to 0 ). However, some differences were observed in TSC values as a function of the hydrolysis conditions. Indeed, while proteins \#1, 2, 6, 8, 14, 18, and 19 were similarly digested by Alcalase ${ }^{\circledR}$, as shown by the TSC detected for all conditions, the in vitro digestion of proteins \#5, 13, 15, 16, and 17 was more efficient for the simultaneous treatment than for control and pretreated conditions. Only proteins \#4, 9, 10 and 18 were resistant to pepsin hydrolysis, with TSC values < 10, regardless of the hydrolysis conditions (control and pressurization treatments). Protein \#1 was not hydrolyzed by any treatment, since similar TSC values were obtained for all conditions. When compared to conventional hydrolysis at atmospheric pressure $(0.1 \mathrm{MPa})$, the application of pressurization treatments $(380 \mathrm{MPa}$ for $1 \mathrm{~min}$ ) before or simultaneous to hydrolysis improved the in vitro digestion of proteins \#6, 11, 12, $13,14,15,16,17$, and 19 . The hydrolysis of proteins \#2, 5, 8, 15, and 19 was enhanced by pretreatment, as compared to control and simultaneous conditions, but the hydrolysis of protein \#3 was unaffected.

\section{Discussion}

The purpose of this study was to evaluate the effects of Alcalase ${ }^{\circledR}$ and pepsin hydrolysis under HHP processing conditions on the hydrolysis of allergenic proteins from mealworms. Our results provide the first evidence that HHP-assisted enzymatic hydrolysis by Alcalase ${ }^{\circledR}$ at $380 \mathrm{MPa}$ for $1 \mathrm{~min}$ improved the degree of hydrolysis of mealworm proteins at an early stage of hydrolysis as well as in vitro digestion of allergenic proteins. Contrary to Alcalase ${ }^{\circledR}, \mathrm{HHP}$-assisted enzymatic hydrolysis by pepsin did not improve the degree of hydrolysis of mealworm proteins. However, the high pressure used as pretreatment condition enhanced the in vitro digestion of allergenic proteins by pepsin.

\subsection{Effects of High Hydrostatic Pressure-Assisted Enzymatic Hydrolysis on Protein Degradation and Degree of Hydrolysis}

Our results showed that Alcalase ${ }^{\circledR}$ hydrolysis of mealworm proteins under HHP (simultaneous condition-380 MPa for $1 \mathrm{~min}$ ) improved the degree of hydrolysis by 24 and 22\% after 60 min of hydrolysis when compared to the control and pretreated conditions, respectively (Figure 2), despite no major changes being observed in terms of protein degradation during hydrolysis (Figure 1). This non-correlation between SDS-PAGE profiles and degree of hydrolysis results could be explained by the generation of very low molecular weight peptides (largely < to $10 \mathrm{kDa}$ ), which could not be detected due to their migration outside the gel. Consequently, and specifically regarding the degree of hydrolysis, the result indicates that HHP treatment might have facilitated the mealworm protein conformational changes that are needed to increase the effectiveness of enzymatic digestion by providing Alcalase ${ }^{\circledR}$ access to the buried cleavage site at the very beginning of hydrolysis (until $10 \mathrm{~min}$ ). Previous studies using various enzymes demonstrated that HHP-assisted enzymatic hydrolysis induced the exposure of new cleavage sites through protein unfolding, which enhanced enzyme activity, reduced hydrolysis time [36], and improved the degree of hydrolysis and concentration of peptides generated in protein hydrolysates [37-39]. In addition, the DH of mealworm proteins obtained was significantly increased ( $p$ $<0.05)$ during HHP-assisted enzymatic hydrolysis by Alcalase ${ }^{\circledR}$. This increase was drastically improved as compared to the control $(0.1 \mathrm{MPa})$ (Figure 2A), but was lower than similar studies [38,40,41], where $\mathrm{DH}$ increases ranged from $17 \%$ to $58 \%$ for pressure-treated protein hydrolysates as compared to the control (0.1 MPa). The effectiveness of HHP treatment on the enzymatic hydrolysis depends on specific parameters, such as substrate/enzyme ratio, pressure level, and treatment duration. Consequently, different hypotheses could explain the lack of influence of HHP on the in vitro digestion of mealworm protein. First, the duration of HHP treatment $(1 \mathrm{~min})$ was too short to induce optimal unfolding 
of mealworm proteins to improve Alcalase ${ }^{\circledR}$ access to buried sites. Second, irreversible protein aggregation occurring during the commercial-scale production of mealworm meals could decrease the efficiency of HHP and enzymatic hydrolysis. Indeed, the mealworm powders that were used for this study were roasted at approximately $107^{\circ} \mathrm{C}$ and ground from fresh larvae [42]. When using the same mealworm powder from Entomo Farm, Stone et al. (2019) observed that the heating step of the insects during processing could result in protein denaturation, exposing hydrophobic groups and leading to protein aggregation [42]. Womeni et al. [43] demonstrated that roasting and grinding enhanced the aggregation of proteins, which makes the insect products unsuitable for food formulations due to their low solubility. A recent study published by Kröncke et al. [44] confirmed that oven drying of T. molitor larvae decreased the quality of proteins and reduced their solubility by $74 \%$ [44]. Consequently, the large amount of protein aggregates generated during production of mealworm meal rendered HHP ineffective for unfolding the proteins, leaving certain bonds in T. molitor proteins buried and inaccessible to Alcalase ${ }^{\circledR}$, which decreased the proteolysis efficiency $[45,46]$. This second hypothesis is especially appealing given the large MW protein aggregates that were observed in the sodium dodecyl sulfate-polyacrylamide gel electrophoresis (SDS-PAGE) wells for control, pretreated, and simultaneous Alcalase ${ }^{\circledR}$ experimental conditions, and could explain why no significant DH was observed between the control and pretreatment conditions. Contrary to Alcalase ${ }^{\circledR}$ hydrolysis, coupling $\mathrm{HHP}$ and pepsin had no impact on the DH of mealworm proteins, despite the differences of protein degradation profiles observed in Figure 1. As mentioned for Alcalase ${ }^{\circledR}$, it is difficult to correlate the results obtained in Figure 1; Figure 2, since very low molecular weight peptides could not be not detected in electrophoresis gels. The short duration of HHP treatment and the presence of protein aggregates in mealworm meal could explain the inability of HHP to improve protein digestion in vitro, as hypothesized for Alcalase ${ }^{\circledR}$. Cleavage specificities are also important, since Alcalase ${ }^{\circledR}$ has broad specificity, hydrolyzing most peptide bonds. It preferentially hydrolyzes those containing aromatic amino acid residues whereas pepsin is more specific and cleaves peptide bonds following Phe or Tyr residues, as well as other hydrophobic amino acids. The recent study of Dai et al. [47] confirmed the importance of enzyme specificity during hydrolysis of T. molitor larva protein, since Alcalase ${ }^{\circledR}$ was the most efficient enzyme in terms of degree of hydrolysis compared to various other commercial enzymes (trypsin, Neutrase, papain, and pepsin) [47].

\subsection{Digestion of Mealworm Allergenic Proteins by Pressurization Treatments}

Recent publications demonstrated cross-reactivity between edible insects and other Arthropoda (crustaceans, mite), identifying different proteins that are involved in muscle contraction (actin, myosin, tropomyosin, troponin $\mathrm{T}$ and $\mathrm{C}$, tubulin), in enzymatic pathways (arginine kinase 1, alpha-amylase) or part of the hemolymphatic system (hexamerin 1 and 2) as pan-allergens [48]. Globally, the results that are presented in Table 1 showed that pepsin was more efficient than Alcalase ${ }^{\circledR}$ for hydrolysis of allergenic mealworm proteins, despite the fact that, on the whole, the DH that was obtained with Alcalase ${ }^{\circledR}$ was higher (Figure 2). Our results also demonstrated that HHP, applied as a pretreatment before in vitro digestion or simultaneously with enzymatic hydrolysis, improved the in vitro digestion of specific mealworm allergenic proteins. These results are consistent with previous publications evaluating the effects of HHP coupled to enzymatic hydrolysis on the potential allergenicity of major protein allergens from different food matrices [49-52]. Indeed, after HHP-assisted enzymatic hydrolysis, these protein hydrolysates exhibited non-antigenic properties that were superior to those of proteins only treated with enzymatic hydrolysis. The production of hydrolysates with lower immunoreactivity from pressure-treated native protein is induced by increasing the protein susceptibility to enzymatic action by exposing new cleavage sites that allow for the proteases to reach otherwise buried hydrolysis sites.

However, our work also showed that HHP-assisted enzymatic hydrolysis had a limited effect on tropomyosin, myosin heavy chain, troponin, and tubulin proteolysis, as measured by TSC and enzyme efficiency when compared to the control condition. In the literature, the efficiency of Alcalase ${ }^{\circledR}$ and pepsin for the hydrolysis of these specific insect allergenic proteins has been scarcely reported. 
Tropomyosin from shrimp, being classed as arthropods, was sensitive to HHP, since pressurization at $500 \mathrm{MPa}$ for $10 \mathrm{~min}$ combined with thermal treatment at $55^{\circ} \mathrm{C}$ decreased the protein allergenicity by $73.59 \%$ as compared to a boiling treatment [52]. However, tropomyosin is usually reported as heat stable and resistant to gastrointestinal digestion [53]. More specifically, it was demonstrated that pepsin could only slightly hydrolyze oyster tropomyosin, which demonstrated that tropomyosin has relatively good resistance to this enzyme. Nevertheless, Mejrhit et al. [54] found that shrimp tropomyosin IgE binding was decreased after heat and pepsin treatments. Hall, Johnson, and Liceaga [19] demonstrated that Alcalase ${ }^{\circledR}$ hydrolysis of cricket protein changed the binding characteristics of cricket tropomyosin to IgE, which indicated the susceptibility of tropomyosin to Alcalase ${ }^{\circledR}$ proteolysis. Similar results were obtained using house cricket Acheta domesticus, desert locust Schistocerca gregaria and yellow mealworm T. molitor [4]. To the best of our knowledge, there are no previous reports on the impact of Alcalase ${ }^{\circledR}$ or pepsin hydrolysis, coupled or not to HHP, on the vitro digestion of myosin heavy chain, troponin and tubulin from edible insects. However, Deng et al. [55] reported that pepsin was efficient for the proteolysis of myosin heavy chain and troponin from shrimp, while Alcalase ${ }^{\circledR}$ was often used for the hydrolysis of muscle proteins from meat and fish-based products [56]. Consequently, the low number of TSC for muscular mealworm proteins after enzymatic hydrolysis or the similar number of TSC obtained for control and pressurization conditions can be explained by irreversible protein aggregation induced by HHP, which drastically decreased the proteolytic activity of both Alcalase ${ }^{\circledR}$ and pepsin used at atmospheric pressure or in combination with HHP.

\section{Conclusions}

This preliminary study demonstrated that HHP-assisted enzymatic hydrolysis by Alcalase ${ }^{\circledR}$ improved the degree of hydrolysis of mealworm protein at the very beginning of digestion, despite no modification of protein degradation profiles. Moreover, pressurization treatments that were coupled to hydrolysis by Alcalase ${ }^{\circledR}$ and pepsin further increased the in vitro digestion of specific allergenic proteins. However, the presence of protein aggregates in the initial mealworm meal powder decreased the efficiency of enzymatic hydrolysis and pressurization treatment. Nevertheless, this work has produced encouraging results by combining HHP and enzymatic hydrolysis for the proteolysis of allergenic mealworm proteins. Besides, experiments are currently under way in order to understand the impact of HHP parameters on the denaturation and aggregation of edible insect proteins. Further research on native mealworm proteins extracted from fresh larvae and subject to minimal heat treatment is necessary to improve the combination of HHP and enzymatic hydrolysis.

Author Contributions: Conceptualization, A.B. and A.D.; Methodology, A.B., A.D.; Software, A.B.; Validation, A.B., S.M., Y.P., and A.D.; Formal Analysis, A.B.; Investigation, A.B. and A.D.; Resources, A.B., V.P., J.C., S.M., Y.P., and A.D.; Data Curation, A.B.; Writing-Original Draft Preparation, A.B. and A.D.; Writing-Review \& Editing, A.B., V.P., J.C., S.M., Y.P. and A.D.; Visualization, A.B. and A.D..; Supervision, A.D.; Project Administration, A.D.; Funding Acquisition, A.D. All authors have read and agreed to the published version of the manuscript.

Funding: This research was funded by the Le Fonds de recherche du Québec-Nature et technologies (Grant \# 2018-PR-208090 to Alain Doyen).

Acknowledgments: The authors thank Sylvie Bourassa and Victor Fourcassie for their assistance with proteomics analysis. The authors also thank Diane Gagnon and Dany Boisvert for technical support.

Conflicts of Interest: The authors declare no conflict of interest.

\section{References}

1. Yi, L.; Lakemond, C.; Sagis, L.M.; Eisner-Schadler, V.; Van Huis, A.; Van Boekel, M. Extraction and characterisation of protein fractions from five insect species. Food Chem. 2013, 141, 3341-3348. [CrossRef] [PubMed]

2. Purschke, B.; Meinlschmidt, P.; Horn, C.; Rieder, O.; Jäger, H. Improvement of techno-functional properties of edible insect protein from migratory locust by enzymatic hydrolysis. Eur. Food Res. Technol. 2017, 244, 999-1013. [CrossRef] 
3. Mintah, B.K.; He, R.; Dabbour, M.; Xiang, J.; Agyekum, A.A.; Ma, H. Techno-functional attribute and antioxidative capacity of edible insect protein preparations and hydrolysates thereof: Effect of multiple mode sonochemical action. Ultrason. Sonochem. 2019, 58, 104676. [CrossRef] [PubMed]

4. Pali-Schöll, I.; Meinlschmidt, P.; Larenas-Linnemann, D.; Purschke, B.; Hofstetter, G.; Rodríguez-Monroy, F.A.; Einhorn, L.; Mothes-Luksch, N.; Jensen-Jarolim, E.; Jäger, H. Edible insects: Cross-recognition of IgE from crustacean- and house dust mite allergic patients, and reduction of allergenicity by food processing. World Allergy Organ. J. 2019, 12, 100006. [CrossRef]

5. Van Broekhoven, S.; Bastiaan-Net, S.; De Jong, N.W.; Wichers, H.J. Influence of processing and in vitro digestion on the allergic cross-reactivity of three mealworm species. Food Chem. 2016, 196, 1075-1083. [CrossRef]

6. Barre, A.; Caze-Subra, S.; Gironde, C.; Bienvenu, F.; Bienvenu, J.; Rougé, P. Entomophagie et risque allergique. Rev. Française d'Allergol. 2014, 54, 315-321. [CrossRef]

7. Ozawa, H.; Umezawa, K.; Takano, M.; Ishizaki, S.; Watabe, S.; Ochiai, Y. Structural and dynamical characteristics of tropomyosin epitopes as the major allergens in shrimp. Biochem. Biophys. Res. Commun. 2018, 498, 119-124. [CrossRef]

8. Broekman, H.C.; Knulst, A.; Jager, S.D.H.; Monteleone, F.; Gaspari, M.; De Jong, G.; Houben, G.F.; Verhoeckx, K. Effect of thermal processing on mealworm allergenicity. Mol. Nutr. Food Res. 2015, 59, 1855-1864. [CrossRef]

9. Liu, G.-M.; Cheng, H.; Nesbit, J.B.; Su, W.-J.; Cao, M.-J.; Maleki, S. Effects of boiling on the IgE-Binding properties of tropomyosin of shrimp (Litopenaeus vannamei). J. Food Sci. 2010, 75, T1-T5. [CrossRef]

10. De Gier, S.; Verhoeckx, K. Insect (food) allergy and allergens. Mol. Immunol. 2018, 100, 82-106. [CrossRef]

11. Villa, C.; Moura, M.B.M.V.; Costa, J.; Mafra, I. Immunoreactivity of lupine and soybean allergens in foods as affected by thermal processing. Foods 2020, 9, 254. [CrossRef] [PubMed]

12. Chen, L.; Phillips, R.D. Effects of twin-screw extrusion of peanut flour on in vitro digestion of potentially allergenic peanut proteins. J. Food Prot. 2005, 68, 1712-1719. [CrossRef] [PubMed]

13. Ketnawa, S.; Liceaga, A.M. Effect of microwave treatments on antioxidant activity and antigenicity of fish frame protein hydrolysates. Food Bioprocess Technol. 2016, 10, 582-591. [CrossRef]

14. Yang, W.; Tu, Z.; Wang, H.; Zhang, L.; Gao, Y.; Li, X.; Tian, M. Immunogenic and structural properties of ovalbumin treated by pulsed electric fields. Int. J. Food Prop. 2017, 20, S3164-S3176. [CrossRef]

15. Wang, C.; Xie, Q.; Wang, Y.; Fu, L. Effect of ultrasound treatment on allergenicity reduction of milk casein via colloid formation. J. Agric. Food Chem. 2020, 68, 4678-4686. [CrossRef]

16. Kato, T.; Katayama, E.; Matsubara, S.; Omi, Y.; Matsuda, T. Release of allergenic proteins from rice grains induced by high hydrostatic pressure. J. Agric. Food Chem. 2000, 48, 3124-3129. [CrossRef]

17. Li, H.; Zhu, K.; Zhou, H.; Peng, W. Effects of high hydrostatic pressure treatment on allergenicity and structural properties of soybean protein isolate for infant formula. Food Chem. 2012, 132, 808-814. [CrossRef]

18. Dong, X.; Wang, J.; Raghavan, V. Critical reviews and recent advances of novel non-thermal processing techniques on the modification of food allergens. Crit. Rev. Food Sci. Nutr. 2020, 1-15. [CrossRef]

19. Hall, F.; Johnson, P.; Liceaga, A.M. Effect of enzymatic hydrolysis on bioactive properties and allergenicity of cricket (Gryllodes sigillatus) protein. Food Chem. 2018, 262, 39-47. [CrossRef]

20. Hall, F.; Liceaga, A.M. Effect of microwave-assisted enzymatic hydrolysis of cricket (Gryllodes sigillatus) protein on ACE and DPP-IV inhibition and tropomyosin-IgG binding. J. Funct. Foods 2020, 64, 103634. [CrossRef]

21. Butz, P.; Tauscher, B. Emerging technologies: Chemical aspects. Food Res. Int. 2002, 35, 279-284. [CrossRef]

22. Janssen, R.H.; Vincken, J.-P.; Broek, L.A.V.D.; Fogliano, V.; Lakemond, C. Nitrogen-to-protein conversion factors for three edible insects: Tenebrio molitor, Alphitobius diaperinus, and Hermetia illucens. J. Agric. Food Chem. 2017, 65, 2275-2278. [CrossRef] [PubMed]

23. Spinelli, J.; Lehman, L.; Wieg, D. Composition, Processing, and utilization of red crab (Pleuroncodes planipes) as an aquacultural feed ingredient. J. Fish. Res. Board Can. 1974, 31, 1025-1029. [CrossRef]

24. Zhang, T.; Jiang, B.; Miao, M.; Mu, W.; Li, Y. Combined effects of high-pressure and enzymatic treatments on the hydrolysis of chickpea protein isolates and antioxidant activity of the hydrolysates. Food Chem. 2012, 135, 904-912. [CrossRef]

25. Curl, A.L.; Jansen, E.F. Effect of high pressures on trypsin and chymotrypsin. J. Biol. Chem. 1950, 184, 45-54.

26. Le Roux, K.; Berge, J.P.; Baron, R.; Leroy, E.; Arhaliass, A. Extraction of Chitins in a Single Step by Enzymatic Hydrolysis in an Acid Medium. U.S. Patent Application No. 14/122,427, 10 April 2014. 
27. De Holanda, H.D.; Netto, F.M. Recovery of components from shrimp (Xiphopenaeus kroyeri) processing waste by enzymatic hydrolysis. J. Food Sci. 2006, 71, C298-C303. [CrossRef]

28. Church, F.C.; Swaisgood, H.E.; Porter, D.H.; Catignani, G.L. Spectrophotometric assay using o-phthaldialdehyde for determination of proteolysis in milk and isolated milk proteins. J. Dairy Sci. 1983, 66, 1219-1227. [CrossRef]

29. Hall, F.; Jones, O.G.; O'Haire, M.E.; Liceaga, A.M. Functional properties of tropical banded cricket (Gryllodes sigillatus) protein hydrolysates. Food Chem. 2017, 224, 414-422. [CrossRef]

30. Nesvizhskii, A.I.; Keller, A.; Kolker, E.; Aebersold, R. A statistical model for identifying proteins by tandem mass spectrometry. Anal. Chem. 2003, 75, 4646-4658. [CrossRef]

31. Lundgren, D.H.; Hwang, S.; Wu, L.; Han, D.K. Role of spectral counting in quantitative proteomics. Expert Rev. Proteom. 2010, 7, 39-53. [CrossRef]

32. Liu, H.; Sadygov, R.G.; Yates, J.R. A model for random sampling and estimation of relative protein abundance in shotgun proteomics. Anal. Chem. 2004, 76, 4193-4201. [CrossRef] [PubMed]

33. Qian, W.-J.; Jacobs, J.M.; Camp, D.G.; Monroe, M.E.; Moore, R.J.; Gritsenko, M.A.; Calvano, S.E.; Lowry, S.F.; Xiao, W.; Moldawer, L.L.; et al. Comparative proteome analyses of human plasma followingin vivo lipopolysaccharide administration using multidimensional separations coupled with tandem mass spectrometry. Proteomics 2005, 5, 572-584. [CrossRef]

34. Old, W.M.; Meyer-Arendt, K.; Aveline-Wolf, L.; Pierce, K.G.; Mendoza, A.; Sevinsky, J.R.; Resing, K.A.; Ahn, N.G. Comparison of label-free methods for quantifying human proteins by shotgun proteomics. Mol. Cell. Proteom. 2005, 4, 1487-1502. [CrossRef] [PubMed]

35. Barre, A.; Simplicien, M.; Cassan, G.; Benoist, H.; Rougé, P. Food allergen families common to different arthropods (mites, insects, crustaceans), mollusks and nematods: Cross-reactivity and potential cross-allergenicity. Rev. Française d'Allergol. 2018, 58, 581-593. [CrossRef]

36. Garcia-Mora, P.; Peñas, E.; Frias, J.; Gomez, R.; Martinez-Villaluenga, C. High-pressure improves enzymatic proteolysis and the release of peptides with angiotensin I converting enzyme inhibitory and antioxidant activities from lentil proteins. Food Chem. 2015, 171, 224-232. [CrossRef]

37. Franck, M.; Perreault, V.; Suwal, S.; Marciniak, A.; Bazinet, L.; Doyen, A. High hydrostatic pressure-assisted enzymatic hydrolysis improved protein digestion of flaxseed protein isolate and generation of peptides with antioxidant activity. Food Res. Int. 2019, 115, 467-473. [CrossRef]

38. Nazir, M.A.; Mu, T.; Zhang, M. Preparation and identification of angiotensin I-converting enzyme inhibitory peptides from sweet potato protein by enzymatic hydrolysis under high hydrostatic pressure. Int. J. Food Sci. Technol. 2019, 55, 482-489. [CrossRef]

39. Boukil, A.; Suwal, S.; Chamberland, J.; Pouliot, Y.; Doyen, A. Ultrafiltration performance and recovery of bioactive peptides after fractionation of tryptic hydrolysate generated from pressure-treated $\beta$-lactoglobulin. J. Membr. Sci. 2018, 556, 42-53. [CrossRef]

40. Ahmed, J.; Mulla, M.; Al-Ruwaih, N.; Arfat, Y.A. Effect of high-pressure treatment prior to enzymatic hydrolysis on rheological, thermal, and antioxidant properties of lentil protein isolate. Legum. Sci. 2019, 1, 10. [CrossRef]

41. Al-Ruwaih, N.; Ahmed, J.; Mulla, M.F.; Arfat, Y.A. High-pressure assisted enzymatic proteolysis of kidney beans protein isolates and characterization of hydrolysates by functional, structural, rheological and antioxidant properties. LWT 2019, 100, 231-236. [CrossRef]

42. Stone, A.K.; Tanaka, T.; Nickerson, M. Protein quality and physicochemical properties of commercial cricket and mealworm powders. J. Food Sci. Technol. 2019, 56, 3355-3363. [CrossRef] [PubMed]

43. Womeni, H.M.; Tiencheu, B.; Linder, M.; Nabayo, C.; Martial, E.; Tenyang, N.; Tchouanguep Mbiapo, F.; Villeneuve, P.; Fanni, J.; Parmentier, M. Nutritional value and effect of cooking, drying and storage process on some functional properties of Rhynchophorus phoenicis. Int. J. Life Pharma Res. 2012, 2, 203-219.

44. Kröncke, N.; Böschen, V.; Woyzichovski, J.; Demtröder, S.; Benning, R. Comparison of suitable drying processes for mealworms (Tenebrio molitor). Innov. Food Sci. Emerg. Technol. 2018, 50, 20-25. [CrossRef]

45. Mulvihill, D.; Fox, P. Proteolysis of $\alpha$ s1-casein by chymosin: Influence of pH and urea. J. Dairy Res. 1977, 44, 533-540. [CrossRef]

46. Agboola, S.O.; Dalgleish, D.G. Enzymatic hydrolysis of milk proteins used for emulsion formation. 1. Kinetics of protein breakdown and storage stability of the emulsions. J. Agric. Food Chem. 1996, 44, 3631-3636. [CrossRef] 
47. Dai, C.; Ma, H.; Luo, L.; Yin, X. Angiotensin I-converting enzyme (ACE) inhibitory peptide derived from Tenebrio molitor (L.) larva protein hydrolysate. Eur. Food Res. Technol. 2013, 236, 681-689. [CrossRef]

48. Leni, G.; Tedeschi, T.; Faccini, A.; Pratesi, F.; Folli, C.; Puxeddu, I.; Migliorini, P.; Gianotten, N.; Jacobs, J.; Depraetere, S.; et al. Shotgun proteomics, in-silico evaluation and immunoblotting assays for allergenicity assessment of lesser mealworm, black soldier fly and their protein hydrolysates. Sci. Rep. 2020, 10. [CrossRef]

49. Chicón, R.; Belloque, J.; Alonso, E.; Martín-Álvarez, P.J.; López-Fandiño, R. Hydrolysis under high hydrostatic pressure as a means to reduce the binding of $\beta$-lactoglobulin to immunoglobulin E from human sera. J. Food Prot. 2008, 71, 1453-1459. [CrossRef]

50. Peñas, E.; Préstamo, G.; Polo, F.; Gomez, R. Enzymatic proteolysis, under high pressure of soybean whey: Analysis of peptides and the allergen Gly $\mathrm{m} 1$ in the hydrolysates. Food Chem. 2006, 99, 569-573. [CrossRef]

51. Zhou, H.; Wang, C.; Ye, J.; Tao, R.; Chen, H.; Cao, F. Effects of enzymatic hydrolysis assisted by high hydrostatic pressure processing on the hydrolysis and allergenicity of proteins from ginkgo seeds. Food Bioprocess Technol. 2016, 9, 839-848. [CrossRef]

52. Long, F.; Yang, X.; Wang, R.; Hu, X.; Chen, F. Effects of combined high pressure and thermal treatments on the allergenic potential of shrimp (Litopenaeus vannamei) tropomyosin in a mouse model of allergy. Innov. Food Sci. Emerg. Technol. 2015, 29, 119-124. [CrossRef]

53. Palmer, L. Edible Insects as a Source of Food Allergens. Master's Thesis, University of Nebraska-Lincoln, Lincoln, NE, USA, 2016.

54. Mejrhit, N.; Azdad, O.; Chda, A.; El Kabbaoui, M.; Bousfiha, A.; Bencheikh, R.; Tazi, A.; Aarab, L. Evaluation of the sensitivity of Moroccans to shrimp tropomyosin and effect of heating and enzymatic treatments. Food Agric. Immunol. 2017, 28, 969-980. [CrossRef]

55. Deng, S.-G.; Lutema, P.C.; Gwekwe, B.; Li, Y.; Akida, J.S.; Pang, Z.; Huang, Y.; Dang, Y.; Wang, S.; Chen, M.; et al. Bitter peptides increase engulf of phagocytes in vitro and inhibit oxidation of myofibrillar protein in peeled shrimp (Litopenaeus vannamei) during chilled storage. Aquac. Rep. 2019, 15, 100234. [CrossRef]

56. Muguruma, M.; Ahhmed, A.M.; Katayama, K.; Kawahara, S.; Maruyama, M.; Nakamura, T. Identification of pro-drug type ACE inhibitory peptide sourced from porcine myosin B: Evaluation of its antihypertensive effects in vivo. Food Chem. 2009, 114, 516-522. [CrossRef]

(C) 2020 by the authors. Licensee MDPI, Basel, Switzerland. This article is an open access article distributed under the terms and conditions of the Creative Commons Attribution (CC BY) license (http://creativecommons.org/licenses/by/4.0/). 